\title{
Formation of Organizational Culture: Motivative Approach
}

\author{
ANTON MELNYK ${ }^{1}$, TETYANA LEPEYKO ${ }^{2}$, OLGA MYRONOVA ${ }^{3}$, OKSANA MAZORENKO ${ }^{4}$ \\ Department of Management and Business, SIMON KUZNETS KHARKIV NATIONAL UNIVERSITY OF ECONOMICS, \\ UKRAINE, \\ ${ }^{1}$ E-mail: 13mao@ukr.net \\ 2E-mail: lepeyko.tetyana@gmail.com \\ ${ }^{3} \mathrm{E}$-mail: olga.myronova@hneu.net \\ ${ }^{4}$ E-mail: oksana.mazorenko@gmail.com
}

\begin{abstract}
An important factor in formation an organizational culture is the analysis of motivational factors that have impact on organizational culture. This paper aims to determine motivational indicators that have a significant impact on the organizational culture of the enterprise. Implementation of the motivational function of organizational culture implies the use of monetary and non-monetary motivational indicators. Motivation of employees in a listed way allow to develop effective organizational culture. The use of the suggested motivators for increasing efficiency of organizational culture makes it possible to significantly increase the effectiveness of personnel management in the company. For competent formation of the organizational culture in Ukraine together with monetary indicators companies should implement non-monetary indicators and specific motivators which have significant impact on the organizational culture. In the future, the list of motivational indicators will allow to develop a list of effective measures to improve the organizational culture of the company.
\end{abstract}

Keywords: Organizational culture; Motivational function; Motivational indicators; Motivators; Non-motivators.

JEL Classification: C83, M14 


\title{
Formación de la Cultura Organizativa: Enfoque Motivacional
}

\author{
ANTON MELNYK ${ }^{1}$, TETYANA LEPEYKO ${ }^{2}$, OLGA MYRONOVA ${ }^{3}$, OKSANA MAZORENKO ${ }^{4}$ \\ Department of Management and Business, SIMON KUZNETS KHARKIV NATIONAL UNIVERSITY OF ECONOMICS, \\ UKRAINE, \\ ${ }^{1}$ E-mail: 13mao@ukr.net \\ 2E-mail: lepeyko.tetyana@gmail.com \\ ${ }^{3} \mathrm{E}$-mail: olga.myronova@hneu.net \\ ${ }^{4}$ E-mail: oksana.mazorenko@gmail.com
}

\begin{abstract}
RESUMEN
Un factor importante en la formación de una cultura organizativa es el análisis de los factores de motivación que tienen impacto en la cultura organizativa. El objetivo de este trabajo es determinar los indicadores de motivación que tienen un impacto significativo en la cultura organizativa de la empresa. La implementación de la función motivacional de la cultura organizacional implica el uso de indicadores motivacionales monetarios y no monetarios. La motivación de los empleados de forma listada permite desarrollar una cultura organizativa eficaz. El uso de los motivadores sugeridos para aumentar la eficacia de la cultura organizativa permite aumentar significativamente la eficacia de la gestión del personal en la empresa. Para la formación competente de la cultura organizativa en Ucrania, junto con los indicadores monetarios, las empresas deberían implementar indicadores no monetarios y motivadores específicos que tienen un impacto significativo en la cultura organizativa. En el futuro, la lista de indicadores de motivación permitirá elaborar una lista de medidas eficaces para mejorar la cultura organizativa de la empresa.
\end{abstract}

Palabras clave: Cultura organizativa; Función motivacional; Indicadores motivacionales; Motivadores; No motivadores.

Clasificación JEL: C83, M14

Recibido: 04 de abril de 2021

Aceptado: 12 de junio de 2021 


\section{Introduction}

Modern business uses in its activity advanced technologies and equipment, qualitative information and telecommunication systems, high skilled personnel, ecological materials etc. But combination of all these factors of production sometimes not bringing success and competitiveness of the company in the long-term perspective. At the same time, one of the most important factors for achieve success is that company should have well organized management. The effective management is the ability to combine all productive factors and personnel and to lead everyone in the company to the personal and organizational success. The basis of successful company management is the trust to people. People should believe in the management, values of the company, strategic objectives of the business and benefits which they get as personnel of the company. All of these is formed organizational culture of the company. So, it is possible to say that today's worldwide business society is characterized through the importance of effective organizational culture in the company.

This tendency is actual and for Ukrainian business. Without a doubt, organizational culture is a driving forces for successful development and functioning of the enterprises. In recent years, the significance of organizational culture has become increasingly recognized by both foreign and domestic (Ukrainian) scientists and managers. But all features of organizational culture formation are not sufficiently investigated yet. So, it is necessary to identify the most influential elements during the formation of an organizational culture.

Organizational culture in the organization has many functions, such as guarding, integrating, regulating, adaptive, orienting, educational, motivational, and others. All of them are extremely important. However, many of them are sufficiently explored and understandable in its implementation in the practical life. Regarding the motivational function, there are still many points of view (Saqib et al 2019).

So, the purpose of the study is to investigate the role of motivational function in formation an effective organizational culture of the company and to identify important motivative factors in this process.

The identified motivative factors includes combination of motivators and non-motivators for employees by different categories. This is a basis for implementing the motivational function through listed measures in formation an effective organizational culture of the company.

\section{Literature review}

\subsection{The role of motivation in the organizational culture}

There are many approaches to defining the notion of "organizational culture". Let's consider in more detail the most widespread and, in the opinion of the authors, the most expedient in the context of the study.

First of all, Usachova (2003) distinguishes rational-pragmatic and phenomenological approaches to the definition of "organizational culture". Representatives of the rational-pragmatic approach are Milner (2012), Blyzniuk (2018) et al. This approach consists in defining the organizational culture as an attribute of the organization (a set of norms, values, rules, rituals, traditions, symbols of the organization), which can be influenced. Phenomenological approach, which is represented by Monastyrskyi (2014), is to determine the organizational culture through its essence as a system of representations that indirectly influences the climate in the organization, group interest in achieving organizational goals. It should be noted that the above approaches are quite interesting, because they characterize the organizational culture not only from the position of its essence, but also from the standpoint of causes and the way of its occurrence.

Literature analysis allowed to identify the most popular approaches to defining the concept "organizational culture": managerial and socio-psychological. According to B. Milner (2012), the managerial approach sees organizational culture as rules, traditions, rituals and symbols of 
organization, people's convictions, their relationship with each other and the external environment. Wahyuningsih et al. (2019) analyze organizational culture as a shared identity and links between members leads to eliminate any differences in attitudes, values, behaviors derived from varied cultural backgrounds. Both approaches are used in the studies of H. Monastyrskyi (2014). He considered this concept as a set of certain elements, a techniques and rules of organization and formation of relations between groups of employees, and as a tool to create a healthy psychological climate in an organization for creating certain ethical, moral and cultural values. The analysis of the approaches to the definition of "organizational culture" made it possible to conclude that the most expedient, according to the authors' opinion, is the using of a set of approaches - managerial and sociopsychological.

Thus, organizational culture is a set of important norms, values, rules, rituals, symbols, traditions, morals, etc., that are accepted by all members of the organization, form the features of interpersonal behavior in the organization, and have a mediated influence on the organization relationship with the external environment.

Panagiotis, M., et al. (2014) note that organizational culture plays a vital role in an organization activity. It is an important indicator of the organization's productivity and effectiveness. The role and significance of organizational culture in a concentrated form are manifested in its functions. Functions of organizational culture reflect: its essential characteristics, directions of research, importance in the system of management for improvement company effectiveness (Malyarets et. al., 2021). One of the significant functions in the meaning of organizational culture is motivational function because of the people's main role in the organizational culture formation. Hartmann, A. (2006) explained organizational culture as a provider the incentives required for motivating organizational members to generate and transfer knowledge by including employees in decision making process. Bohatska (2015) notes that in Ukraine the motivational work involved only interviewing a potential employee; and the motivation is often considered only as wages. The author also notes that a properly organized motivation system helps to significantly improve the efficiency of the staff. Bovykin (2004) is noted that motivation is the process of unifying the goals of the enterprise and the goals of the employee to more fully meet the greater need of both and a system of different ways of influencing the staff to achieve the goals of both - the employee and the enterprise (Perevozova et al., 2019). Acceptance the goals of the enterprise by the absolute majority of employees is indicating the construction of an effective organizational culture.

\subsection{The motivational indicators which affect an organizational culture}

Ismiyarto, et al. (2015), Hartmann, A. (2006), Yusof, H. S. M., et al. (2017), Muizu, W. O. Z., Sari D. (2019), Budiyono (2019) notice that motivation is the main force for formatting effective organizational behavior. It is important to generate the system of motivational indicators that would make it possible to influence on the organizational culture effectiveness.

Ismiyarto, et al. (2015) focused on using in the system of motivation indicators as need, desire, tension, unhappiness and hope, and should be different for all individuals / employees. O. Prodius and M. Oleksiiev (2015) suggest that an enterprise-level motivation system should create trust between managers and employees, provide guarantees of employment for all employees, and guarantee fair labor remuneration. Yusof, H. S. M., et al. (2017) said that the relationship between organizational culture and employee motivation is explained by work attitude. V. Vasiuta (2016) notes that with the help of motivation the organization of the best specialists is simplified, and labor activity is increased. Also, the author notes the importance of motivation in the long-term influence in order to change the parameters in the structure of its values and interests of the team. According to N. Bohatska (2015) one of the most important motivational mechanisms is the effective dialogue between management and personnel.

S. Haiduchenko in (Haiduchenko, 2013) notes that in the process of motivation stimulation of workers perform the set of functions: (1) economic, because effective incentives for the employee 
contribute to the increase of overall labor productivity; (2) social, because when the employee receives income, he provides himself with a certain complex of economic and social benefits; (3) socialpsychological, because stimulation affects the formation of the employees' inner world - their needs and values, orientations and attitudes, motives of labor behavior and attitude to work; (4) moraleducational, through which the moral qualities of an employee are formed.

So, in the recent theoretical and empirical studies it is absent fully understanding of most significant motivational indicators in formation an effective organizational culture of the company. Firstly, it is necessary to make theoretical analysis of motivational indicators which have impact on organizational culture. Secondly, it is needed to identify those motivational indicators which are significant for employees in different countries.

\section{Data and methodology}

For implementing motivational approach to the organizational culture formation, it is needed to analyze role of monetary indicators. This study based on statistical analysis of the official data about level of unemployment and wage arrears (Bezrobittia naselennia (za metodolohiieiu MOP) za stattiu, typom mistsevosti ta vikovymy hrupamy, 2019; Zaborhovanist iz vyplaty zarobitnoi platy, 2019).

For assessing the main motivators for Ukrainian employees in this study the questionnaire survey method to Ukrainian employees is used. The questionnaire was based on Report "Employee Motivation 2018: Living to Work" (2018). The research was conducted in the Ukrainian companies. The number of staff involved in the survey was a thousand employees.

The questionnaire used in this study consists of 2 groups of questions:

1) To identify relation between motivated and not motivated employees in Ukraine,

2) To investigate reasons of employee motivation and causes of motivation absence.

Among the main questions the survey included are the following: overall job satisfaction / dissatisfaction; the most important methods of motivation - monetary, non-monetary; the most significant monetary and non-monetary motivational factors, their reasons; the most significant demotivate factors, their reasons.

We have chosen as data analysis technique the statistical analysis of the data for building trends of macroeconomic factors which have impact on monetary indicators of employee motivation.

The statistical analysis with radar method were used for evaluating top motivators and top nonmotivators for employees by age categories.

The descriptive statistic method was used for analyzing the survey results about reasons of employee motivation and causes of motivation absence. It was an attempt to range the most significant indicators of the formation of an effective organizational culture.

\section{Results}

In Ukraine the role of monetary indicators is maintained, but according to current economic situation, using of monetary motivators sometimes impossible.

Let's analyze the main tendencies in Ukrainian economy. First of all, one of the main indicators of country's economic situation is the level of unemployment (Fig. 1). Next important indicator of country's economic situation is the level of wage arrears. The Fig. 2 shows the Ukrainian tendency of wage arrears in 2015-2019.

The chart illustrated that in Ukraine in 2019 the level of unemployment is decreased comparing with all considered periods but it's still high (8.2\%). Comparing with end of 2018 the level of unemployment is decreased by $0.6 \%$. Due to forecast pandemic of COVID-19 will lead to increasing the level of unemployment up $12 \%$

The given figure allows to conclude that in Ukraine big amount of wages are not paid in time. These tendencies indicate a crisis economic situation in Ukraine. In addition, it is characterized by inflation of 
the national currency; encroachment on the integrity of the Ukrainian lands; increasing of the product's prices; low competitiveness of the domestic enterprises. According to this, for the main part of companies it is difficult to use monetary methods for personnel motivation. So, it is needed for the companies to implement nonmonetary methods of motivation for effective organizational culture formation.

Figure 1 Level of unemployment in Ukraine, \%

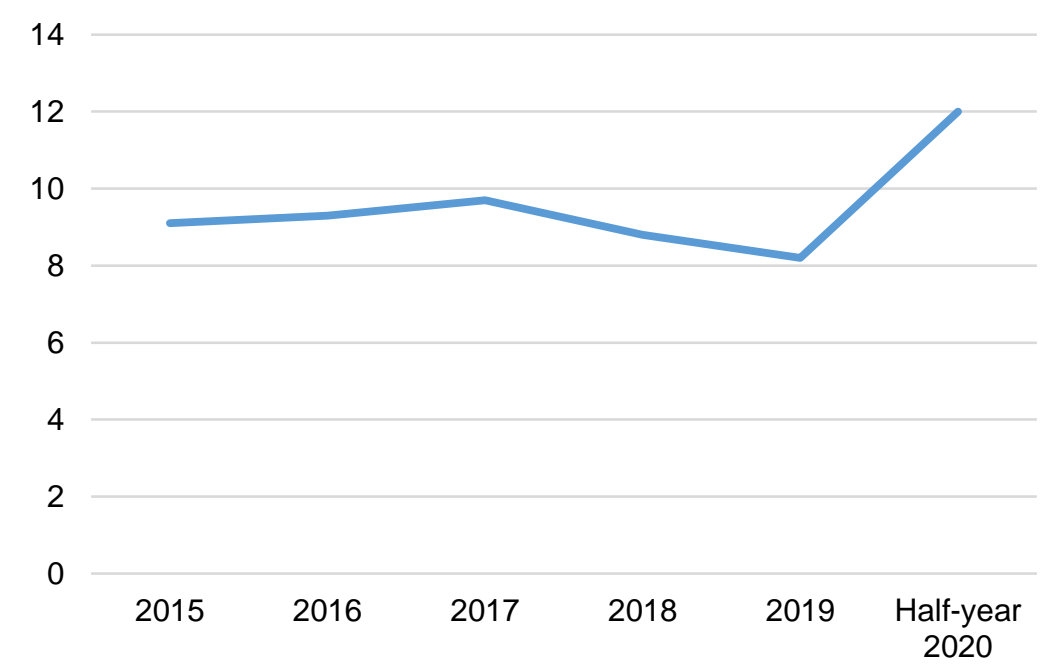

Source: Unemployment of the population (according to the ILO methodology) by sex, type of area and age groups, (2019)

Figure 2 Level of wage arrears in Ukraine, mln UAH

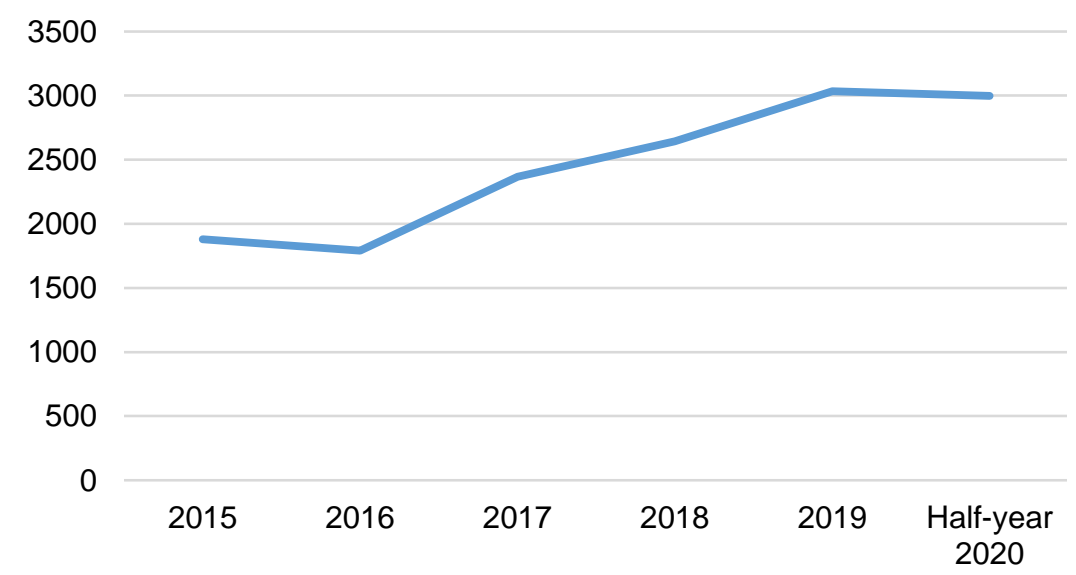

Source: Wage arrears, (2019)

According to Report "Employee Motivation 2018: Living to Work" (Report "Employee Motivation 2018: Living to Work", 2018) from 2000 full-time employees who participates in the survey in 2017 $82 \%$ are motivated employees. And in 2018 the number of motivated employees is decreased to $71 \%$. Results of survey shown that in UK number of people who not motivated at work is increased in 2018 by $9 \%$ comparing with 2017. The same tendency is observed in Ukraine in 2019 (Fig. 3).

The number of not motivated employees is more than in UK. The main reason of this difference is low level of waged and financial stability in Ukraine. In this case, people in Ukraine are less motivated in general. At the same time, the most part of Ukrainian employees is understanding current economic situation in the country and, in addition to monetary motivators, want to get something more from their work - non-monetary motivators.

For understanding reasons of employee motivation and causes of motivation absence it is necessary to investigate responses from employees about important motivators or not motivators at the work. 
Based on the Report "Employee Motivation 2018: Living to Work" (Report "Employee Motivation 2018: Living to Work", 2018) it was created questionnaire which has some questions: (1) What do motivate you at work? (2) What do not motivate you at work? (3) What are the most significant indicators of the formation of an effective organizational culture?

Figure 3 Results of survey about motivated employees in Ukraine

Year 2018

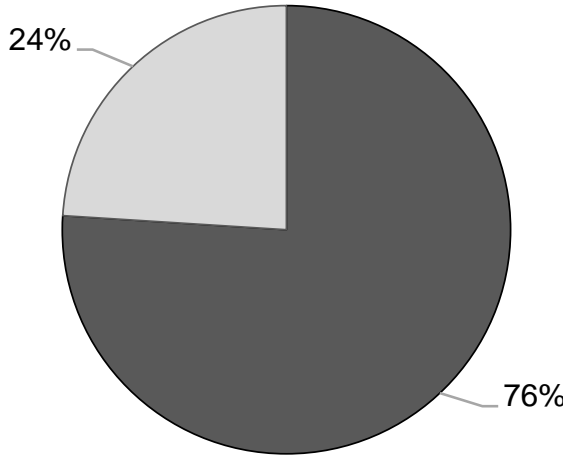

$\square$ Motivated $\square$ Not motivated
Year 2019

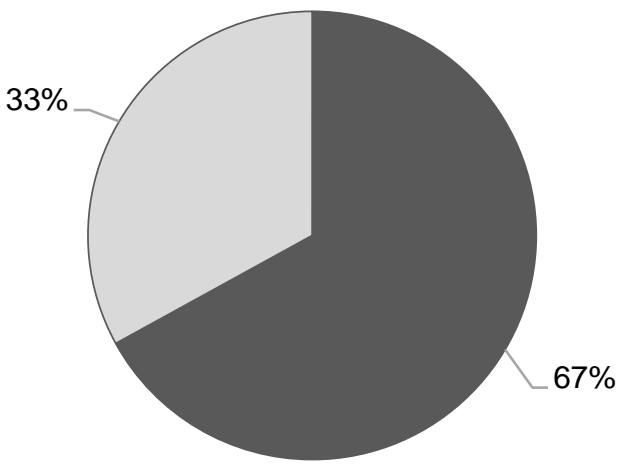

- Motivated $\square$ Not motivated

Source: Report “Employee Motivation 2018: Living to Work”, 2018

During the research one thousand employees of different companies in Ukraine answered for these questions. According answer for the question "What do motivate you at work?" responses from respondents are presented:

1) Good relation work / life: $21 \%$.

2) Good challenge who motivate each other: $20 \%$.

3) My both is very thankful: $15 \%$.

4) Organization climate is motivating: $12 \%$.

5) My boss is very professional, he/she motivates me: $12 \%$.

Given results allow to conclude that the most important motivators for employees are: good relation between work and life (21\%) and good colleagues who motivate each other (20\%). It means that people want to work for doing their life better but not live for work, have the rest, spend afterworking time for their families etc. The third place in the list of top motivators is thankfulness from the boss (15\%). The employees want to fill their significance for the company and hear "thanks" from the manager for good job. This is normal psychological desire of all people. Next important motivators are good social-psychological climate and professionalism of manager ( $12 \%$ both). It allows to make conclusion about importance of good communication in the organization, low conflict level, professional manager who can show good example to follow him/her.

These are general results of survey about top motivators for employees. But there is significant difference of the respondents' answers according to their age. Results of the most important motivators at work by ages are presented in Fig. 4.

Thus, for the youngest people (18-24 years old) the most important motivators good colleagues and good relation between work and life. It is obvious because for this age category the need of personal life is very high. And they want to communicate with their colleagues informally during the working time and after it. The less important motivator for employees in this age category is level of organization climate. This is due to the face that these people are not considering their work as a life. It's just source for the life. 
For employees in the age categories 25-34 and 35-44 there are no big difference between four motivators: good relation between work and life; good colleagues; high level of organizational climate; and manager professionalism.

Figure 4 Results of survey about top motivators for employees by age categories

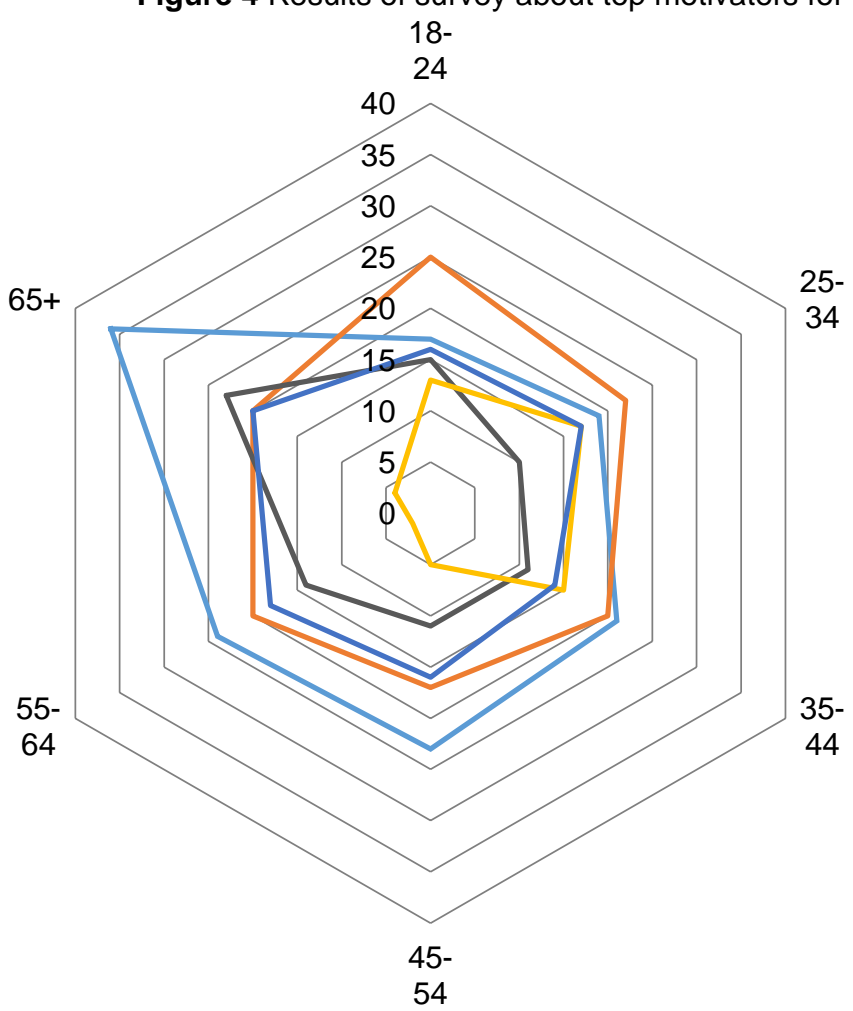

Good relation work/life

$25-$

34

Good colleagues who motivate each other

My boss is very thankful

Organization climate is motivating

My boss is very professional, he/she motivates well

But for them it is not so important thankfulness from the boss because in this age psychologically it is not very valuable their significance for the company. For these age categories some priorities are changed. For 25-34 age category the most important is good colleagues in the company which is inherent to younger people. For 35-44 age category the good relation between work and life has significant role because this period is often characterized by marriage, the birth of children, that lead to time needs for the families.

For employees in the age categories 45-54 still the most important motivator stays good relation between work and life. For these employees the role of thankfulness from manager is increased very fast. And at the same time importance of good social-psychological climate in the organization is greatly decreased.

For oldest employees (more than 65 years old) the most significant motivator is good relation between work and life. Because these people need more time for the rest, families etc. After that the important motivator is hearing "thank you" from manager. For these employees this means their great importance for the company. The same ranks of motivators for this age category employees are good colleagues and manager professionalism. And the less significant motivator for them is level of organizational climate.

So, given analysis allow to conclude that there are age differences in the ranking of top motivators at the work.

According to the main not motivators (answers for the question "What do not motivate you at work?") the results are

1) Absence of career perspectives: $25 \% /$

2) Poor communication manager / subordinates: $25 \%$.

3) Company does not provide regular rewards and recognition: $24 \%$. 
4) Poor relation work / life: $21 \%$

5) Work does not challenge me: $18 \%$.

The results of survey shown that the biggest not-motivators are absence of career perspectives and poor communications between manager and subordinates ( $25 \%$ both); absence of regular rewards and recognition in the company (24\%); poor relation between work and life (21\%); and insufficient challenge at the work (18\%).

\section{Discussion}

Let's consider reasons of this rank list of not motivators. In Ukraine the level of unemployment is very high and low pace of company development. In this case, very often very professional employees with good practical experience can't take higher position in their organization and can't find good position in another companies. So, they don't satisfy by their job position and manager and don't make efforts at the work. Next important not-motivator is not enough rewards and recognition. All people want to get rewards for their efforts. And if they not get rewards and recognition once, next time they will not make efforts for better outcomes. Fourth place is taken by poor relation between work and life. If employees are working over-time and not get appropriate to their efforts rewards this is not motivated them in the future. The less important in this rank list but with very significant value $(18 \%$ of respondents) is absence of challenge at the work. For modern very changeable environment is very important to be in trend. In this case, employees want to develop themselves but day-to-day activity doesn't challenge people and, as a result, doesn't motivate.

Also, as for top motivators, there are significant difference of the respondents' answers according to their age. Results of the most important not-motivators at work by ages are presented in Fig. 5 .

Figure 5 Results of survey about top not-motivators for employees by age categories

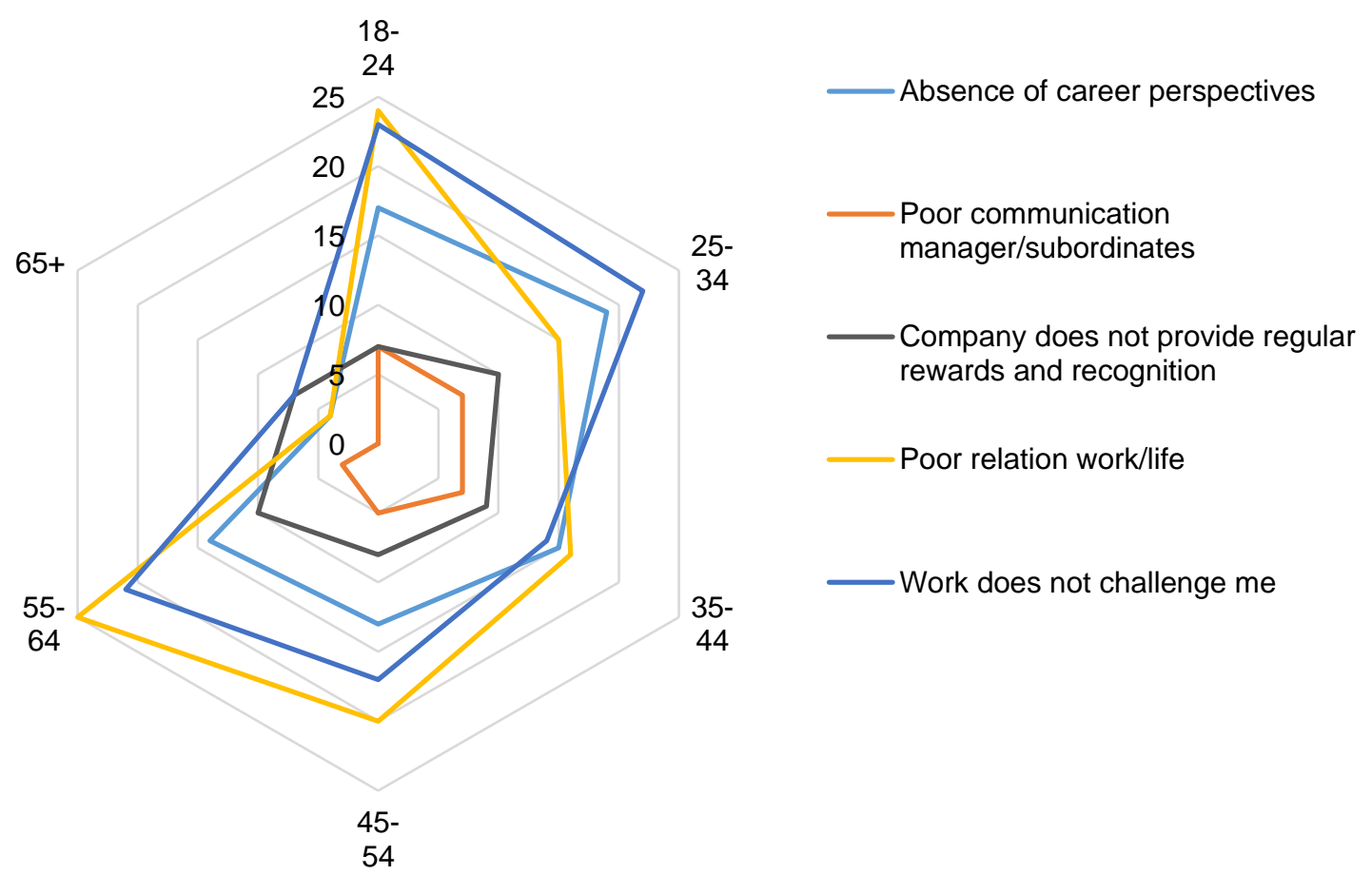

The given figure is illustrated the great features of different age categories. Thus, the biggest notmotivator for age categories 18-25, 35-44, 45-54 and 55-64 is poor relation between work and life. This tendency is expected because good relation between work and life is one of the most important motivators for these employees. For youngest employees (age 18-24 and 25-34) the most important not-motivator is absence of challenge at the work. This is explained by the psychology of youth, their striving for achievements, high level of creativity and faith in the future. For oldest employees (age 
category 65+) the most important not-motivators are absence of career perspectives (the main part of companies don't give possibility for them to improve their career position according to age) and not regular rewards and recognition (people in this age category have a lot of additional expenses for maintaining their health). For all of the age categories the less important not-motivator is poor communication between manager and subordinates.

For the question "What are the most significant indicators of the formation of an effective organizational culture?" respondents' answers are:

1) Financial security

2) Health and well-being

3) Job security

4) Challenge and motivation

5) Career perspective
$29 \%$.

$27 \%$.

$26 \%$.

$25 \%$.

$24 \%$.

The results are illustrated that the main part of respondents think that for formation of an effective organizational culture, firstly, employees should have financial stability (29\% of respondents). Second place in the formation of an effective organizational culture takes health and well-being of employees ( $28 \%$ of respondents). At the third place is job security ( $26 \%$ of respondents). The fourth place in the list of top-five indicators get presence of challenge in the work and high level of motivation $(25 \%$ of respondents). The lowest rank has career perspectives ( $24 \%$ of respondents).

So, the main prerequisite for the formation of an effective organizational culture is that today's employees want to see at the work the opportunities for future and maintain their personal approach, goals, and lifestyle.

\section{Conclusion}

Thus, the analysis allowed to highlight the main motivational indicators, which can affect the organizational culture of the enterprise.

Theoretical analysis shown that there are two main groups of motivational indicators which can have impact on organizational culture efficiency in the company. Based on the further analysis it was possible to conclude that in Ukraine the most effective indicators are still monetary indicators. But according to the crisis economic situation, not all companies can implement them. In this case, the role of non-monetary indicators is increased. For understanding the most significant motivators and notmotivators for Ukrainian employees, the survey was carried out.

The made research allows to do the following conclusions:

1) Each of age group told about importance of relation between work and life.

2) Each of age group focused that their colleagues increase their motivation.

3) The presence of a manager who says "thank you" has a significant impact on how employees feel.

4) All respondents paid attention on importance to build trustful communication between manager and subordinates.

5) All respondents testified importance of rewards and recognition in increasing and maintaining high level of motivation in the company.

Thus, for formation the effective organizational culture it is necessary to motivate personnel in such ways (in addition to monetary methods):

1) providing a challenge to employees at work;

2) giving them the opportunity to think in another way;

3) providing the possibility of career growth;

4) building effective communications between manager and subordinates. 
When companies implement measures to motivate employees in the listed ways, the efficiency of organizational culture will significantly increase.

\section{References}

1. Afshari, L., et al. (2020). Organizational Culture, Social Capital, and Knowledge Management: An Integrated Model. International Journal of Knowledge Management, 16, 2, 52-66. https://doi.org/10.4018/IJKM.2020040104.

2. Blyzniuk, T., (2018). The relationship between the stage of the company's life cycle and the type of its organizational culture. Scientific Bulletin of Kherson State University. Economic Sciences Series, 30, 1, 76-79.

3. Bohatska, N., (2015). Motivation as the main factor in improving work efficiency at an enterprise. Global and national problems of economics, 3, 210-214.

4. Bovykin, V., (2004). New management: solving management problems. Tenfold increase in capital growth rates. Economics, Moscow.

5. Budiyono, (2019). Motivation of work, organizational culture, and organizational commitment towards work productivity lecturers and employees of economics college AAS SURAKARTA (STIE AAS SURAKARTA). Humanities \& Social Sciences Reviews, 7(5), 226-236. https://doi.org/10.18510/hssr.2019.7528.

6. Haiduchenko, S., (2013). Personnel motivation. KhNUMH, Kharkiv.

7. Hartmann, A. (2006). The role of organizational culture in motivating innovative behaviour in construction firms. Construction Innovation, 6, 3, 159-172. https://doi.org/10.1108/14714170610710712.

8. Ismiyarto, et al. (2015). Organizational Culture, Motivation, Job Satisfaction and Performance of Employees toward the Implementation of Internal Bureaucracy Reform in the Ministry for the Empowerment of State Apparatus and Bureaucracy Reform (The Ministry of PANRB). Journal of Management and Sustainability, 5, 1, 192-199. https://doi.org/10.5539/jms.v5n1p192.

9. Malyarets, L., lastremska, O., Herashchenko, I., lastremska, O., Babenko, V. (2021). Optimization of Indicators for Management of Enterprise: Finance, Production, Marketing, Personnel. Estudios de Economía Aplicada, Vol. 38-3(1), pp. 1-13. http://dx.doi.org/10.25115/eea.v38i4.4028

10.Milner, B. Z., (2012). Theory of organization. INFRA-M, Moscow.

11.Monastyrskyi, H. L., (2014). Theory of organization. TNEU, Ternopil.

12.Muizu, W. O. Z., Sari D. (2019) improving employee performance through organizational culture, leadership, and work motivation: survey on banking organizations in Southeast Sulawesi. Jurnal Bisnis dan Manajemen, 20, 1, 71-88. https://doi.org/10.24198/jbm.v20i1.266.

13.Panagiotis, M., et al. (2014). Organizational Culture and Motivation in the Public Sector. The Case of the City of Zografou. Procedia Economics and Finance, 14, 415-424. https://doi.org/10.1016/S2212-5671(14)00730-8.

14.Perevozova, I., Daliak, N., Babenko, V. (2019). Modeling of Financial Support for the Competitiveness of Employees in the Mining Industry. CEUR Workshop Proceedings, vol. 2422, pp. 444-454. URL: http://ceur-ws.org/Vol-2422/paper36.pdf

15.Pogrebnyak, V. A., (2005). The culture of the organization as an object of regular management. Enterprise management issues, 1(13), 54-59.

16.Prodius, O., Oleksiiev, M., (2015). Personnel motivation is the main factor in increasing the efficiency of the enterprise. Scientific Bulletin of the Odessa National Economic University, 12, 188200. Retrieved from http://nbuv.gov.ua/UJRN/Nv_2015_12_17.

17.Report "Employee Motivation 2018: Living to Work", (2018). Personnel today, October, 2. Retrieved from https://www.motivates.co.uk/wp-content/uploads/2019/08/employee-motivation-report2018-living-to-work.pdf.

18.Rynkevich, N. (2020). Features of organizational culture development of the enterprise in the field of information services. Effective economy, 3. https://doi.org/10.32702/2307-2105-2020.3.151. Retrieved from http://www.economy.nayka.com.ua/?op=1\&z=7743. 
19.Saqib, M. N., Kiani, J., Shahzad, B., Anjum, A., \& Ahmad, N. (2019). Anonymous and formally verified dual signature based online e-voting protocol. Cluster Computing, 22(1), 1703-1716.

20.Unemployment of the population (according to the ILO methodology) by sex, type of area and age groups, (2019). State Statistics Service of Ukraine. Retrieved from: http://www.ukrstat.gov.ua/operativ/operativ2017/rp/eans/eans_u/arch_bnsmv_u.htm.

21. Usachova, V. V. (2003), Organizational culture in transitive economics: political aspect, dissertation of the candidate of sciences, Donetsk National University, Donetsk.

22.Vasiuta, V., (2016). Personnel motivation at the enterprise in modern business conditions. Effective economy, 6. Retrieved from http://www.economy.nayka.com.ua/?op=1\&z=5041.

23.Wage arrears, (2019). State Statistics Service of Ukraine. Retrieved from http://www.ukrstat.gov.ua/operativ/operativ2015/gdn/prc_rik/prc_rik_u/dsz_u_U.html.

24. Wahyuningsih, S. H., et al. (2019). Analysis of organizational culture with denison's model approach for international business competitiveness. Problems and Perspectives in Management, 17(1), 142 151. https://doi.org/10.21511/ppm.17(1).2019.13.

25.Yusof, H. S. M., et al. (2017). The relationship between organizational culture and employee motivation as moderated by work attitude. Journal of Administrative and Business Studies, 3(1), 21-25. https://doi.org/10.20474/jabs-3.1.3. 